\title{
Aplikasi Pembelian Tiket Pesawat: Memahami Determinan Niat untuk Melanjutkan Penggunaan
}

\author{
Selfira Salsabilla ${ }^{1^{*}}$, Muamar Nur Kholid ${ }^{2}$, Yestias Maharani ${ }^{3}$ \\ 1, 2, 3 Universitas Islam Indonesia \\ ${ }^{1}$ selfirasalsabilla@uii.ac.id, ${ }^{2}$ muamar.nk@uii.ac.id, 3yestias.maharani@uii.ac.id \\ ${ }^{*}$ Penulis korespondensi
}

\begin{abstract}
Currently airplane passengers in Indonesia have a wide selection of airplane ticket purchase applications (PTP Application). The existence of various PTP applications in Indonesia makes it easy for users to stop using the PTP application and move to another PTP application. This study aims to identify the factors that influence the customer's intention to continue the use of PTP Application. This study uses the expectation confirmation model (ECM) by adding a trust variable. 203 respondents participated in this study. The model was tested using SmartPLS 2.0. The results of the study show that satisfaction is an important variable that influences the customer's intention to continue using PTP applications. In addition, trust and perceived usefulness have a significant positive effect on the intention to continue using PTP applications. Confirmation and usefulness perceptions have a significant positive effect on satisfaction and trust. This study discusses results of research both in relation to the theoretical and practical context.
\end{abstract}

Keywords: Expectation Confirmation Model (ECM), airline ticket purchase application, trust

\begin{abstract}
Abstrak
Saat ini penumpang pesawat terbang di Indonesia memiliki berbagai pilihan aplikasi pembelian tiket pesawat (Aplikasi PTP). Adanya berbagai aplikasi PTP di Indonesia mengakibatkan pengguna mudah untuk berhenti menggunakan suatu aplikasi PTP dan berpindah ke aplikasi PTP yang lain. Penelitian ini bertujuan untuk mengidentifikasi faktor-faktor yang mempengaruhi niat pengguna untuk melanjutkan penggunaan aplikasi PTP. Penelitian ini menggunakan expectation confirmation model (ECM) dengan menambahkan variabel kepercayaan. 203 responden berpartisipasi dalam penelitian ini. Model diuji dengan menggunakan SmartPLS 2.0. Hasil penelitian menunjukkan bahwa kepuasan merupakan variabel penting yang mempengaruhi niat pengguna untuk melanjutkan penggunaan aplikasi PTP. Selain itu, kepercayaan dan persepsi kegunaan berpengaruh positif signifikan terhadap niat melanjutkan penggunaan aplikasi PTP. Konfirmasi dan persepsi kegunaan berpengaruh positif signifikan terhadap kepuasan dan kepercayaan. Lebih lanjut, penelitian ini mendiskusikan hasil penelitian baik berkaitan dengan ranah teoritis maupun praktis.
\end{abstract}

Kata kunci: Expectation Confirmation Model (ECM), aplikasi pembelian tiket pesawat, kepercayaan 


\section{PENDAHULUAN}

Menurut Badan Pusat Statistik (2017), selama tahun 2016 jumlah penumpang angkutan udara domestik di Indonesia mencapai 80,45 juta penumpang atau naik 16,97\% dibandingkan tahun 2015, sementara jumlah penumpang angkutan udara internasional sebesar 14,78 Juta atau naik 8,16\% dibandingkan tahun 2015. Besarnya jumlah penumpang baik domestik maupun internasional tidak terlepas dari mudahnya akses untuk mendapatkan tiket pesawat. Penelitian Asosiasi Penyelenggara Jasa Internet Indonesia (2016) menyatakan bahwa 63,5\% pengguna internet pernah melakukan transaksi secara online, dimana 25,7\% dilakukan untuk transaksi pembelian tiket, proporsi tersebut merupakan yang terbesar dibandingkan dengan transaksi online untuk kebutuhan rumah tangga 22,2\%, pakaian 3,6\% dan hotel 3,4\%. Hasil tersebut tidak terlepas dari fakta bahwa, menurut penelitian We Are Social Singapore (2017) Indonesia merupakan negara dengan pertumbuhan jumlah pengguna internet terbesar di dunia dengan 132,7 Juta pengguna di akhir 2016 atau naik 51\% dari awal tahun 2016. Dari jumlah tersebut hanya 31\% pengguna internet di Indonesia yang mengakses melalui dekstop dan tablet, yang artinya mayoritas pengguna internet lebih banyak mengakses internet melalui telepon seluler (We Are Social Singapore, 2017).

Proporsi besar penggunaan internet untuk pembelian tiket di Indonesia, tidak terlepas dari banyaknya online travel agent (OTA) yang menyediakan aplikasi pembelian tiket pesawat yang terpasang di smartphone (aplikasi PTP). Beberapa OTA yang menyediakan aplikasi PTP antara lain Traveloka, Tiket.com, Nusatrip, PegiPegi, Utiket, Airpaz dan lain-lain. Selain OTA, beberapa online travel supplier (OTS) juga menyediakan aplikasi PTP antara lain Garuda Indonesia, Airasia, Sriwijaya Air, dan lain-lain. Pada tahun 2015 sudah diperkirakan bahwa wisatawan Indonesia akan banyak menggunakan aplikasi dalam jaringan OTA untuk memenuhi kebutuhan wisata tahun 2016 (Prodjo, 2015). Bahkan penurunan penjualan tiket pesawat melalui gerai travel (offline) sudah mulai dirasakan sejak tahun 2012, karena seiring dengan pembelian tiket secara online (Jati, 2014).

Meskipun terdapat banyak aplikasi PTP yang terus bermunculan, namun tidak banyak penyedia aplikasi PTP yang sukses dengan aplikasinya. Banyaknya aplikasi PTP yang dikembangkan OTA di Indonesia telah memanjakan pengguna dengan berbagai pilihan aplikasi PTP. Hal tersebut mengakibatkan pengguna akan dengan mudah berpindah ke aplikasi PTP yang lain dan menghentikan penggunaan aplikasi PTP yang lama ketika tidak nyaman dengan aplikasi PTP yang lama. Adopsi (initial acceptance) atas suatu teknologi informasi memang menjadi langkah awal yang penting untuk mencapai kesuksesan sebuah teknologi informasi, namun kesuksesan teknologi informasi sangat bergantung pada kemauan pengguna untuk melanjutkan penggunaan teknologi informasi (continuance intention) (Bhattacherjee, 2001). Berkaitan dengan hal tersebut, penelitian ini fokus pada faktor yang mempengaruhi niat pengguna untuk melanjutkan penggunaan aplikasi PTP, bukan pada adopsi aplikasi PTP.

Penelitian ini penting untuk dilakukan karena beberapa alasan. Pertama, penelitian ini hanya fokus pada aplikasi PTP yang tertanam dalam smartphone yang disediakan oleh OTA. Beberapa penelitian terkait pembelian tiket pesawat online sudah dilakukan antara lain AlMaghrabi dkk. (2011); Amaro \& Duarte (2015); Escobar-Rodriguez \& Carvajal-Trujillo (2014); Kim dkk. (2009); F.H. Lee \& Wu (2011); Mohd Suki \& Mohd Suki (2017), namun mayoritas penelitian tersebut dilakukan untuk meneliti pembelian tiket pesawat melalui website (bukan 
aplikasi smartphone). Untuk menutup gap penelitian sebelumnya yang didominasi oleh obyek penelitian berbasis website, penelitian ini fokus pada obyek penelitian berupa aplikasi PTP yang ada dalam smartphone. Penting untuk membedakan dimana teknologi informasi ini digunakan (smartphone atau komputer) karena model penelitian yang menjelaskan perilaku manusia dibatasi oleh karakteristik fungsi tertentu dari teknologi yang dipilih (Cho, 2016). Kedua, mayoritas penelitian pembelian tiket pesawat online, berfokus pada adopsi (initial acceptance) dan tidak berfokus pada keberlanjutan penggunaan, seperti penelitian Jeon, Ali, \& Lee, (2018); Kim dkk., (2009); F. H. Lee \& Wu, (2011); K.-F. Lee, Haque, Maulan, \& Abdullah, (2019); Mohd Suki \& Mohd Suki, (2017). Sebagai bagian untuk memperbaharui penelitian sebelumnya, penelitian ini tidak fokus pada adopsi teknologi informasi untuk pembelian tiket pesawat, namun fokus pada niat pengguna untuk melanjutkan penggunaan aplikasi PTP. Terakhir, penelitian ini berkontribusi terhadap pengembangan literatur kesuksesan teknologi informasi dengan menguji expectation confirmation model (ECM) yang dikembangkan oleh Bhattacherjee, (2001) dengan menambahkan variabel kepercayaan. Penelitian sebelumnya mengenai e-commerce, internet banking, e-payment, dan pembelian tiket pesawat secara online, menemukan peran penting kepercayaan (Alalwan, Baabdullah, Rana, Tamilmani, \& Dwivedi, 2018; Amaro \& Duarte, 2015; Hanafizadeh, Keating, \& Khedmatgozar, 2013; Nguyen \& Hyunh, 2018; Susanto, Chang, \& Ha, 2016).

ECM merupakan sebuah model yang menjelaskan niat pengguna untuk terus menggunakan teknologi informasi. ECM dikembangkan oleh Bhattacherjee (2001) dengan menyesuaikan keputusan pembelian kembali sebuah produk dengan keputusan pengguna untuk melanjutkan penggunaan teknologi informasi. ECM menjelaskan bahwa niat pengguna teknologi informasi untuk melanjutkan penggunaan teknologi informasi ditentukan oleh 3 variabel yaitu konfirmasi (confirmation), kepuasan (satisfaction) dan persepsi kegunaan (perceived usefulness). Dari ketiga variabel tersebut, ECM merumuskan 5 hipotesis penting. Kepuasan pengguna teknologi informasi berpengaruh terhadap niat pengguna untuk melanjutkan penggunaan teknologi informasi. Penelitian dalam bidang pemasaran menemukan pentingnya kepuasan yang akan membuat pembeli membeli kembali produk/ jasa yang diberikan (Szymanski \& Henard, 2001). Karena adanya kesamaan antara keputusan pembelian kembali sebuah produk/jasa dengan keputusan melanjutkan kembali penggunaan teknologi informasi, ECM mengusulkan hubungan yang sama antara kepuasan dan keputusan penggunaan kembali teknologi informasi. Sementara itu, ECM menyatakan bahwa kepuasan dipengaruhi oleh konfirmasi dan persepsi kegunaan. Konfirmasi merupakan persepsi pengguna mengenai kesesuaian harapan penggunaan teknologi informasi dengan kinerja aktual dari teknologi informasi tersebut (Bhattacherjee, 2001). Sementara persepsi kegunaan yang merupakan salah satu jenis harapan setelah menggunakan teknologi informasi merupakan persepsi pengguna mengenai harapan manfaat dari penggunaan teknologi informasi (Davis, Bagozzi, \& Warshaw, 1989). Pengguna teknologi informasi yang mendapatkan keuntungan yang diharapkan setelah penggunaan teknologi informasi, maka akan memiliki pengaruh positif terhadap kepuasan atas teknologi informasi tersebut. Persepsi kegunaan berpengaruh positif terhadap kepuasan berdasarkan penjelasan yang sama dengan konfirmasi (Thong, Hong, \& Tam, 2006). Penelitian dalam bidang pemasaran juga menemukan bahwa harapan yang tinggi maka akan mengakibatkan tingkat kepuasan yang tinggi (Oliver \& DeSarbo, 1988). Lebih lanjut, literatur dalam bidang 
adopsi teknologi informasi menemukan bahwa persepsi kegunaan memiliki pengaruh positif terhadap niat penggunaan teknologi informasi (Venkatesh \& Morris, 2000), karenanya ECM menyimpulkan hal yang sama berkenaan dengan niat melanjutkan penggunaan teknologi informasi. Terakhir ECM menyatakan bahwa tingkat persepsi kegunaan bergantung pada tingkat konfirmasi utamanya ketika persepsi kegunaan awal tidak sesuai dengan kenyataan dari teknologi informasi yang digunakan (Bhattacherjee, 2001).

Beberapa penelitian terdahulu berkenaan dengan E-Commerce telah meneliti peran kepercayaan dan menemukan peran penting kepercayaan (Chen \& Dhillon, 2003). Namun begitu masih ditemukan berbagai macam definisi kepercayaan (Susanto dkk., 2016). Munculnya berbagai macam konsep dan definisi kepercayaan dikarenakan sifat komplek dari kepercayaan dan perubahan lingkungan yang ada (Chen \& Dhillon, 2003). Namun begitu, hasil literatur review oleh Susanto dkk., (2016) menunjukkan bahwa mayoritas penelitian menggunakan definisi kepercayaan yang dibuat oleh Mayer, Davis, Schoorman, Mayer, \& Davis, (1995). Kepercayaan merupakan kesediaan suatu pihak untuk menjadi vulnerable terhadap tindakan pihak lain berdasarkan harapan bahwa pihak lain akan melakukan tindakan tertentu yang penting bagi trustor terlepas dari kemampuan untuk memantau atau mengendalikan pihak lain (Mayer dkk., 1995).

Persepsi kegunaan merupakan variabel penting dalam penjelasan niat pengguna melanjutkan penggunaan teknologi informasi (Venkatesh, Thong, Chan, Hu, \& Brown, 2011). Persepsi kegunaan juga mempengaruhi kepercayaan dalam tahap penerimaan teknologi informasi (Suh \& Han, 2002). Konfirmasi selain mempengaruhi kepuasan juga akan meningkatkan tingkat kepercayaan terhadap teknologi informasi (Susanto dkk., 2016). Kepuasan merupakan hal yang penting dalam pengulangan penggunaan teknologi informasi (Bhattacherjee, 2001). Dimana tingkat kepuasan dipengaruhi oleh kepercayaan yang merupakan belief pasca adopsi (Susanto dkk., 2016; Venkatesh dkk., 2011; Yu, Cao, Gong, \& Adeel, 2018). Sama halnya dengan kepuasan, kepercayaan juga mempengaruhi niat pengguna untuk melanjutkan penggunaan teknologi informasi (Susanto dkk., 2016; Yu dkk., 2018; Zhou, Tsiga, Li, Zheng, \& Jiang, 2018).

Berdasarkan pada uraian diatas, penelitian ini memiliki tujuan untuk menguji ECM yang memiliki tiga variabel penting yaitu konfirmasi, persepsi kegunaan serta kepuasan, dan menambahkan kepercayaan dalam menjelaskan niat pengguna untuk melanjutkan penggunaan aplikasi PTP yang disediakan oleh OTA.

\section{METODE}

Berdasarkan pada literatur review, gambar 1 menyajikan model penelitian dengan menggunakan ECM dengan penambahan variabel kepercayaan. Untuk menguji model tersebut, sampel dipilih dengan menggunakan teknik purposive sampling dengan kriteria responden yang pernah menggunakan aplikasi PTP melalui smartphone untuk membeli tiket pesawat. Kriteria tunggal responden tersebut dalam konteks penelitian niat melanjutkan penggunaan, sejalan dengan penelitian Hong, Thong, \& Tam, (2006); Susanto dkk., (2016). Data dalam penelitian ini didapatkan dengan menggunakan kuesioner online melalui googleform. 209 responden telah berpartisipasi mengisi kuesioner penelitian ini, namun 6 responden tidak mengisi kuesioner dengan lengkap, sehingga untuk analisis data hanya menggunakan 203 responden. 
Gambar 1. Model Penelitian

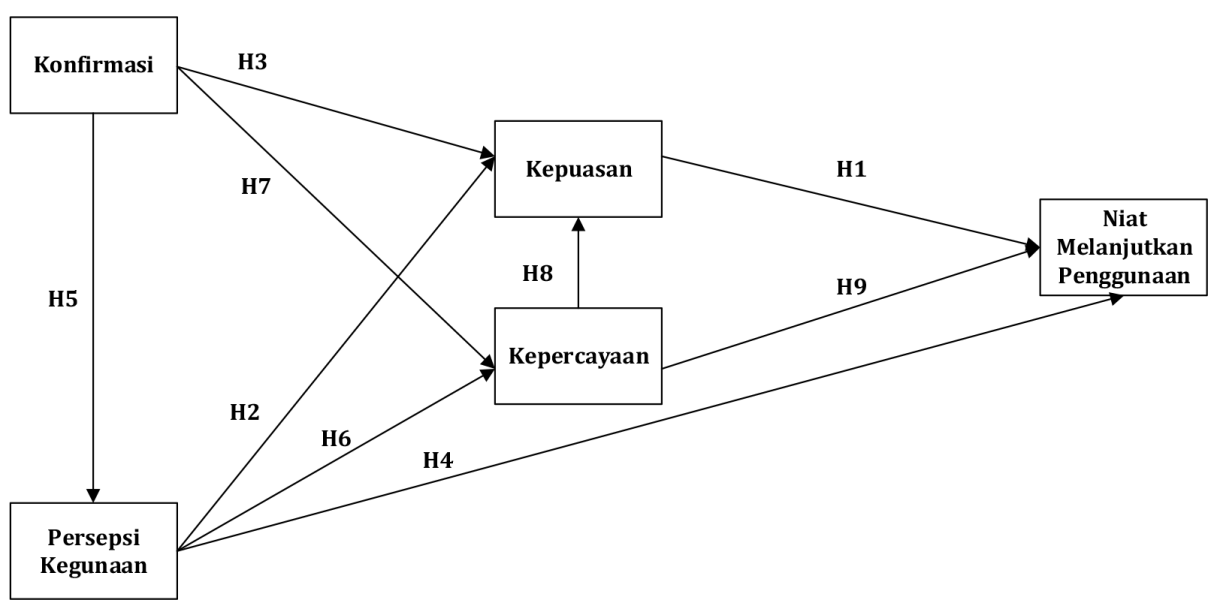

Pengukuran variabel niat melanjutkan penggunaan PTP diukur dengan 3 item pernyataan, konfirmasi diukur dengan 3 item pernyataan, dan persepsi kegunaan diukur dengan 4 item pernyataan. Item pernyataan niat, konfirmasi dan persepsi kegunaan diadopsi dari penelitian Bhattacherjee, (2001). Sementara pengukuran variabel kepuasan diukur dengan 3 item pernyataan yang diambil dari Vila \& Kuster, (2011). Terakhir variabel kepercayaan diukur dengan 4 item pernyataan yang diadopsi dari penelitian Susanto dkk., (2016). Detail pengukuran masing-masing variabel dapat dilihat dalam tabel 1. Penelitian ini menggunakan skala Likert 1 - 6 dari "sangat tidak setuju" hingga "sangat setuju".

Tabel 1. Item Pengukuran Variabel

\begin{tabular}{|c|c|c|}
\hline Variabel & & Pengukuran \\
\hline \multirow{3}{*}{$\begin{array}{l}\text { Niat melanjutkan } \\
\text { penggunaan aplikasi } \\
\text { PTP (continuance } \\
\text { intention) }\end{array}$} & $\mathrm{Cl} 1$ & $\begin{array}{l}\text { Saya akan melanjutkan penggunaan aplikasi PTP, dan tidak bermaksud } \\
\text { menghentikan penggunaan aplikasi tersebut }\end{array}$ \\
\hline & $\mathrm{Cl} 2$ & $\begin{array}{l}\text { Saya akan melanjutkan penggunaan aplikasi PTP dari pada menggunakan cara } \\
\text { lain dalam pemesanan tiket pesawat. }\end{array}$ \\
\hline & $\mathrm{Cl} 3$ & $\begin{array}{l}\text { Saya akan tetap menggunakan aplikasi PTP secara regular seperti yang saya } \\
\text { lakukan sekarang }\end{array}$ \\
\hline \multirow{3}{*}{$\begin{array}{l}\text { Kepuasan } \\
\text { (satisfaction) }\end{array}$} & SA1 & Saya puas dengan aplikasi PTP yang saya download \\
\hline & SA2 & Saya telah membuat keputusan yang benar dengan menggunakan aplikasi PTP \\
\hline & SA3 & Berdasarkan pengalaman saya, saya merasa puas dengan aplikasi PTP \\
\hline \multirow{4}{*}{ Kepercayaan (trust) } & TR1 & Saya percaya dengan aplikasi PTP yang saya gunakan \\
\hline & TR2 & Aplikasi PTP yang saya gunakan, sesuai dengan kepentingan saya \\
\hline & TR3 & Aplikasi PTP yang saya gunakan memberikan akses informasi yang jujur dan benar \\
\hline & TR4 & Aplikasi PTP yang saya gunakan menyediakan pelayanan yang baik \\
\hline \multirow{3}{*}{$\begin{array}{l}\text { Konfirmasi } \\
\text { (confirmation) }\end{array}$} & $\mathrm{C} 1$ & Pengalaman saya menggunakan aplikasi PTP melebihi harapan saya \\
\hline & $\mathrm{C} 2$ & Layanan yang diberikan oleh aplikasi PTP melebihi harapan saya \\
\hline & C3 & Secara keseluruhan, aplikasi PTP sudah sesuai dengan harapan saya \\
\hline \multirow{4}{*}{$\begin{array}{l}\text { Perspektif Kegunaan } \\
\text { (Perceived Usefulness) }\end{array}$} & PU 1 & Saya merasakan manfaat dari penggunaan aplikasi PTP di kehidupan sehari-hari \\
\hline & PU 2 & $\begin{array}{l}\text { Menggunakan aplikasi PTP dapat membantu saya mengerjakan segala sesuatu } \\
\text { lebih cepat }\end{array}$ \\
\hline & PU 3 & Menggunakan aplikasi PTP dapat mendorong produktivitas saya \\
\hline & PU 4 & $\begin{array}{l}\text { Menggunakan aplikasi PTP dapat membantu saya melaksanakan segala sesuatu } \\
\text { dengan lebih baik }\end{array}$ \\
\hline
\end{tabular}


Penelitian ini menggunakan SmartPLS 2.0. untuk menguji model pengukuran maupun model struktural. Model pengukuran berkenaan dengan pengujian reliabilitas menggunakan nilai composite reiability (CR), dimana jika nilai CR tidak kurang dari 0,70 maka sudah dapat dikatakan memenuhi pengujian reliabilitas (Fornell \& Larcker, 1981) Sementara pengujian validitas dilakukan dengan menggunakan convergent dan discriminant validity. Convergent validity akan mengevaluasi item dari variabel adalah benar-benar berhubungan dengan variabelnya. Apabila nilai Average Variance Extracted (AVE) setiap variabel melebihi 0,50 maka sudah dapat dikatakan memenuhi convergent validity (Fornell \& Larcker, 1981). Discriminant validity akan mengevaluasi bahwa korelasi variabel ke variabel itu sendiri lebih besar dari pada korelasi dengan variabel lainnya. Sementara itu, model struktural digunakan dalam rangka menganalisis hubungan antar variabel dalam model penelitian. Model dilakukan pengujian kekuatan model $\left(\mathrm{R}^{2}\right)$, path coefficient, dan signifikansi. Pengujian $\mathrm{R}^{2}$ menganalisa kekuatan model dalam menjelaskan variabel dependen yang diteliti. Sedangkan path coefficient $(\beta)$ dan signifikansi ( $p$-value) merupakan pengujian hipotesa yang dibentuk dalam model.

\section{HASIL DAN PEMBAHASAN}

Tabel 2 menunjukkan hasil pengujian reliabilitas dan convergent validity. Berkenaan dengan convergent validity dapat dilihat bahwa nilai AVE untuk masing-masing variabel berada pada kisaran 0,685 hingga 0,813. Hal tersebut menunjukkan bahwa masing-masing variabel memenuhi kriteria convergent validity karena nilainya lebih dari 0,5. Dilihat dari loading factor dan T-Statistic menunjukkan bahwa item pengukur variabel memiliki loading antara 0,774 hingga 0,937, dengan tingkat signifikansi diatas 1,96 sehingga dapat disimpulkan indikator konstruk dalam model valid.

Tabel 2. Hasil Pengujian Reliabilitas dan Convergent Validity

\begin{tabular}{|c|c|c|c|c|}
\hline Variabel dan Item & Loading & T-Statistics & AVE & CR \\
\hline Niat Melanjutkan & & & 0.700 & 0.875 \\
\hline $\mathrm{Cl} 1$ & 0.886 & 38.167 & & \\
\hline $\mathrm{Cl} 2$ & 0.846 & 10.180 & & \\
\hline $\mathrm{Cl} 3$ & 0.774 & 8.674 & & \\
\hline Konfirmasi & & & 0.708 & 0.879 \\
\hline $\mathrm{CO} 1$ & 0.887 & 22.103 & & \\
\hline $\mathrm{CO} 2$ & 0.776 & 6.646 & & \\
\hline $\mathrm{CO} 3$ & 0.858 & 29.330 & & \\
\hline Persepsi Kegunaan & & & 0.685 & 0.897 \\
\hline PU1 & 0.853 & 22.341 & & \\
\hline PU2 & 0.865 & 15.504 & & \\
\hline PU3 & 0.801 & 10.422 & & \\
\hline PU4 & 0.791 & 9.587 & & \\
\hline Kepuasan & & & 0.813 & 0.929 \\
\hline SA1 & 0.931 & 59.339 & & \\
\hline SA2 & 0.834 & 9.220 & & \\
\hline SA3 & 0.937 & 58.456 & & \\
\hline Kepercayaan & & & 0.724 & 0.913 \\
\hline TR1 & 0.880 & 30.201 & & \\
\hline TR2 & 0.883 & 36.830 & & \\
\hline TR3 & 0.788 & 7.719 & & \\
\hline TR4 & 0.849 & 11.219 & & \\
\hline
\end{tabular}


Tabel 3. Hasil Pengujian Discriminant Validity

\begin{tabular}{lccccc}
\hline \multicolumn{1}{c}{ Variabel } & $\begin{array}{c}\text { Niat } \\
\text { Melanjutkan }\end{array}$ & Konfirmasi & $\begin{array}{c}\text { Persepsi } \\
\text { Kegunaan }\end{array}$ & Kepuasan & Kepercayaan \\
\hline Niat Melanjutkan & 0.836 & & & & \\
Konfirmasi & 0.620 & 0.842 & & & \\
Persepsi Kegunaan & 0.688 & 0.566 & 0.828 & & \\
Kepuasan & 0.750 & 0.709 & 0.708 & 0.902 & 0.851 \\
Kepercayaan & 0.732 & 0.677 & 0.693 & 0.838 & \\
\hline
\end{tabular}

Berkenaan dengan uji reliabilitas dapat dilihat pada nilai composite reliability (CR). Nilai CR berkisar antara 0,875 hingga 0,929 yang menandakan bahwa nilai tersebut diatas 0,7. Hal tersebut menunjukkan bahwa masing-masing pengukuran variabel reliabel. Dilihat dalam tabel 3 nilai akar kuadrat AVE untuk masing-masing variabel lebih besar dari korelasi masing-masing konstruk. Hal tersebut menandakan bahwa uji discriminant validity dapat terpenuhi.

Gambar 2 menyajikan gambar hasil pengujian struktural yang menunjukkan bahwa semua hipotesis dalam model penelitian ini dapat didukung oleh data. Secara lebih rinci, persepsi kegunaan, kepuasan, dan kepercayaan berpengaruh positif signifikan terhadap niat pengguna Aplikasi PTP untuk melanjutkan penggunaan. Pengaruh tersebut termasuk dalam model yang moderat $\left(\mathrm{R}^{2}=63,15 \%\right)$. Berdasarkan pada data yang diolah, kepuasan $(\beta=0,3458)$ memiliki pengaruh besar dari pada pengaruh persepsi kegunaan $(\beta=0,2632)$ dan kepercayaan $(\beta=0,2604)$ dalam mempengaruhi niat untuk melanjutkan penggunaan aplikasi PTP. Hasil ini sejalan dengan penelitian Yu dkk., (2018) Susanto dkk., (2016) dan Thong dkk., (2006) yang menemukan bahwa kepuasan memiliki pengaruh kuat terhadap niat untuk melanjutkan penggunaan aplikasi. Namun hasil ini tidak sesuai dengan penelitian Cho, (2016) dan Hong, Thong, \& Tam, (2006). Hal tersebut menunjukkan bahwa pengguna dalam memutuskan untuk melanjutkan aplikasi PTP sangat mempertimbangkan kepuasannya daripada mengenai kegunaan maupun kepercayaan. Banyaknya aplikasi PTP yang sekarang ini beredar mengakibatkan pengguna memiliki banyak pilihan. Aplikasi PTP relatif tidak berbeda satu sama lain dengan kata lain memiliki kegunaan yang sama. Berkenaan dengan hal tersebut menjadi logis jika pengguna lebih menekankan pada kepuasan penggunaan aplikasi PTP daripada kegunaan aplikasi PTP. Namun begitu, penyedia layanan aplikasi PTP tidak dapat mengabaikan kegunaan aplikasi dan tingkat kepercayaan pengguna karena kedua variabel tersebut terbukti berpengaruh signifikan terhadap niat melanjutkan aplikasi PTP.

Berkenaan dengan kepuasan, hasil penelitian ini menunjukkan bahwa persepsi kegunaan, konfirmasi, dan kepercayaan berpengaruh positif signifikan terhadap kepuasan pengguna aplikasi PTP dengan nilai $\mathrm{R}^{2}=76,03 \%$ yang termasuk dalam kategori model yang kuat. Dimana kepercayaan $(\beta=0,5446)$ memiliki pengaruh lebih besar dari pada konfirmasi $(\beta=0,2246)$ dan persepsi kegunaan $(\beta=0,2240)$. Hasil ini berbeda dengan penelitian Susanto dkk. (2016) dimana kepercayaan bukan merupakan penentu utama dari kepuasan melainkan konfirmasi. Peran penting kepercayaan dalam penentu kepuasan merupakan hal yang logis karena pembelian tiket pesawat bukan merupakan transaksi yang kecil, sehingga pengguna 
tidak akan mudah melakukan transaksi besar tanpa adanya kepercayaan terhadap aplikasi PTP yang digunakan.

Gambar 2. Hasil Pengujian Struktural

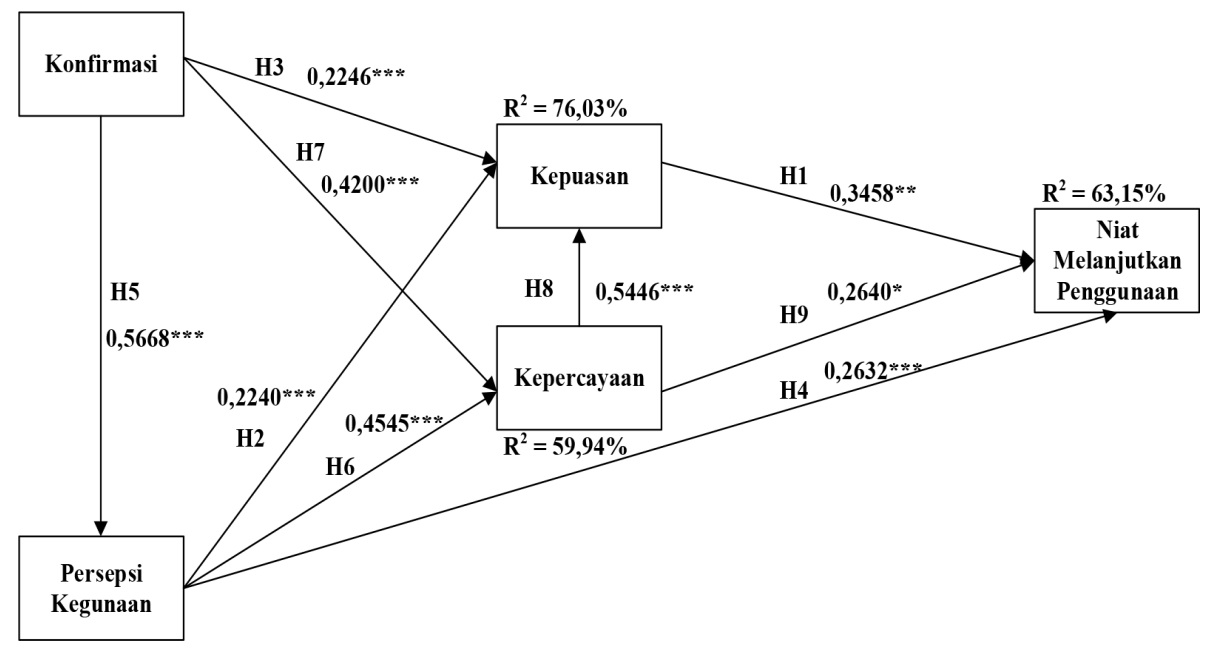

Kepercayaan sebagai penentu utama kepuasan, dipengaruhi oleh konfirmasi dan persepsi kegunaan. Konfirmasi dan persepsi kegunaan berpengaruh positif signifikan terhadap kepercayaan dengan nilai $\mathrm{R}^{2}=59,94 \%$ yang termasuk dalam kategori moderat. Persepsi kegunaan memiliki pengaruh yang lebih besar dari pada pengaruh konfirmasi dalam kaitannya terhadap kepercayaan. Kepercayaan muncul karena adanya kesesuaian harapan pengguna dengan kenyataan yang ada dan juga karena kegunaan dari aplikasi PTP. Namun begitu, kegunaan lebih memiliki peran penting dari pada kesesuaian harapan dengan kenyataan.

Hasil analisis juga menunjukan bahwa pengaruhi konfirmasi terhadap kepercayaan $(\beta=0,4200)$ lebih besar dari pada pengaruh konfirmasi terhadap kepuasan $(\beta=0,2446)$. Sementara itu pengaruh persepsi kegunaan terhadap kepercayaan $(\beta=0,4545)$ juga lebih besar dari pada pengaruh persepsi kegunaan terhadap kepuasan $(\beta=0,2240)$. Dari fakta tersebut dapat diketahui bahwa niat pengguna untuk melanjutkan penggunaan aplikasi PTP sangat dipengaruhi oleh kepuasan, dimana kepuasan sangat dipengaruhi oleh kepercayaan dan kepercayaan dipengaruhi oleh persepsi kegunaan. Fakta ini berbeda dari penelitian sebelumnya yang menekankan pentingnya konfirmasi dari pada persepsi kegunaan (Thong dkk., 2006).

Hasil penelituan ini memiliki kontribusi baik untuk pengembangan dalam ranah teoritis maupun dalam ranah praktik. Dalam konteks teori, penelitian ini mengembangkan dan memvalidasi perluasan model ECM dengan memasukan variabel kepercayaan. Selain itu, penelitian ini juga menyediakan bukti empiris berkaitan dengan model ECM ke dalam obyek teknologi yang baru yaitu aplikasi PTP. Dalam konteks praktik, kepercayaan, kepuasan dan persepsi kegunaan memiliki pengaruh positif signifikan terhadap niat pengguna untuk melanjutkan penggunaan aplikasi PTP. Oleh sebab itu, penyedia aplikasi PTP diharapkan mampu menyusun strategi untuk dapat meningkatkan kepuasan pengguna sehingga diharapkan pengguna akan terus menggunakan aplikasi PTP dari penyedia tersebut. Penyedia aplikasi PTP perlu untuk memenuhi berbagai macam kebutuhan dan permintaan pengguna secara 
efektif dan efisien, sehingga mampu meningkatkan kepuasan pengguna (Susanto dkk., 2016). Dengan begitu, selain memuaskan pengguna yang ada saat ini, hal tersebut juga akan dapat menarik pengguna baru melalui Word of mouth dari pengguna yang puas (Thong dkk., 2006).

Berkaitan dengan kepercayaan, penyedia aplikasi PTP tidak boleh melalaikan faktor kepercayaan pengguna, karena diketahui bahwa kepercayaan merupakan penentu penting dari kepuasan pengguna dan juga niat melanjutkan penggunaan. Karenanya, penting bagi para penyedia aplikasi PTP untuk dapat melakukan berbagai cara untuk dapat meningkatkan kepercayaan pengguna sehingga keberlangsungan usaha penyedia aplikasi PTP dapat berjalan dengan baik. Penyedia aplikasi PTP perlu untuk membangun reputasi aplikasi PTP yang baik agar dapat meningkatkan kepercayaan pengguna (Yu dkk., 2018). Dengan adanya reputasi aplikasi PTP yang baik, maka sangat mungkin untuk dapat mempertahankan pengguna dan menarik pengguna lain yang baru. Selain itu, pengaruh persepsi kegunaan terhadap niat untuk melanjutkan penggunaan juga harus mendapatkan perhatian. Penyedia aplikasi PTP dapat meningkatkan persepsi kegunaan dari pengguna aplikasi PTP melalui iklan atau pemasaran aplikasi PTP yang menonjolkan kegunaan atau kemanfaatan dan keunggulan aplikasi PTP yang dimiliki dibandingkan dengan aplikasi PTP yang lain.

\section{SIMPULAN}

Penelitian ini memperluas kerangka ECM dengan memasukan variabel kepercayaan dalam menjelaskan niat pengguna untuk menggunakan kembali aplikasi PTP. Data dikumpulkan melalui survei dengan kuesioner online. Data diolah dengan alat analisis Smart PLS 2.0. Hasil penelitian menunjukkan bahwa kepercayaan dan kepuasan berpengaruh positif signifikan terhadap niat pengguna menggunakan kembali aplikasi PTP. Konfirmasi, persepsi kegunaan dan kepercayaan berpengaruh positif signifikan terhadap kepuasan, dan konfirmasi berpengaruh positif signifikan terhadap kepercayaan dan persepsi kegunaan. Mengingat model ECM dengan hanya menambahkan kepercayaan masih dalam kategori model yang moderat, penelitian selanjutnya akan lebih baik untuk memperluas ECM dengan menambahkan variabel lain yang relevan. Hal tersebut diharapkan dapat memberikan penjelasan yang lebih baik mengenai faktor yang mempengaruhi niat untuk melanjutkan penggunaan aplikasi PTP.

Berdasarkan pada hasil penelitian yang sudah dilakukan, implikasi penting penelitian ini dalam ranah praktik yaitu menyarankan penyedia aplikasi PTP untuk dapat membuat kebijakan dan menyusun strategi yang dapat menambah dan mempertahankan kepuasan pengguna terhadap aplikasi PTP yang disediakan. Hal ini mengingat kepuasan merupakan faktor penting yang dapat meningkatkan niat pengguna untuk melanjutkan penggunaan aplikasi PTP. Selain itu, penyedia aplikasi PTP juga perlu membuat seperangkat kebijakan yang efektif dan efisien dalam mengelola data pengguna dan memberikan layanan kepada pengguna dengan tujuan untuk meningkatkan kepercayaan pengguna. Hal tersebut perlu dilakukan mengingat kepercayaan menjadi salah satu faktor penting penentu pengguna melanjutkan penggunaan aplikasi PTP. Lebih lanjut, penyedia aplikasi PTP juga perlu untuk menyadarkan pengguna mengenai kegunaan dan keunggulan aplikasi PTP melalui berbagai macam media secara berkesinambungan. 


\section{PUSTAKA ACUAN}

Al-Maghrabi, T., Basahel, A., \& Kamal, M. (2011). What Drives consumers'e-loyalty to Airlines Web Site? Conceptual Framework and Managerial Implications. European, Mediterranean \& Middle Eastern Conference on Information Systems 2011, May 30-31 2011, Athens, Greece, 2011, 416-432. Diakses dari http://www.iseing.org/emcis/EMCISWebsite/ EMCIS2011 Proceedings/SCI9.pdf

Alalwan, A. A., Baabdullah, A. M., Rana, N. P., Tamilmani, K., \& Dwivedi, Y. K. (2018). Examining adoption of mobile internet in Saudi Arabia: Extending TAM with perceived enjoyment, innovativeness and trust. Technology in Society, 55, 100-110. https://doi. org/10.1016/j.techsoc.2018.06.007

Amaro, S., \& Duarte, P. (2015). An integrative model of consumers' intentions to purchase travel online. Tourism Management, 46, 64-79. https://doi.org/10.1016/j.tourman.2014.06.006

Asosiasi Penyelenggara Jasa Internet Indonesia. (2016). Penetrasi dan Perilaku Pengguna Internet Indonesia: Survei 2016. Jakarta.

Badan Pusat Statistik. (2017). Perkembangan Transportasi Nasional Desember 2016. Berita Resmi Statistik (Vol. 12). Jakarta.

Bhattacherjee, A. (2001). Understanding Information Systems Continuance : An ExpectationConfirmation Model. MIS Quarterly, 25(3), 351-370.

Chen, S. C., \& Dhillon, G. S. (2003). Interpreting Dimensions of Consumer Trust in E-Commerce. Information Technology and Management, 4(2), 303-318.

Cho, J. (2016). The impact of post-adoption beliefs on the continued use of health apps. International Journal of Medical Informatics, 87, 75-83. https://doi.org/10.1016/j. ijmedinf.2015.12.016

Davis, F. D., Bagozzi, R. P., \& Warshaw, P. R. (1989). User acceptance of computer technology: a comparison of two theoretical models. Management Science, 35(8), 982-1003. https:// doi.org/10.1287/mnsc.35.8.982

Escobar-Rodriguez, T., \& Carvajal-Trujillo, E. (2014). Online purchasing tickets for low cost carriers: An application of the unified theory of acceptance and use of technology (UTAUT) model. Tourism Management, 43, 70-88. https://doi.org/10.1016/j.tourman.2014.01.017

Fornell, C., \& Larcker, D. (1981). Evaluating structural equation models with unobservable variables and measurement error. Journal of Marketing Research, 18(1), 39-50. https:// doi.org/10.2307/3151312

Hanafizadeh, P., Keating, B. W., \& Khedmatgozar, H. R. (2013). A systematic review of Internet banking adoption. Telematics and Informatics, 31(3), 492-510. https://doi. org/10.1016/j.tele.2013.04.003

Hong, S., Thong, J. Y. L., \& Tam, K. Y. (2006). Understanding continued information technology usage behavior: A comparison of three models in the context of mobile internet. Decision Support Systems, 42(3), 1819-1834. https://doi.org/10.1016/j.dss.2006.03.009

Jati, G. P. (2014). Tergerusnya Penjualan Tiket via Travel. Diakses July 3, 2017, dari http:// www.cnnindonesia.com/ekonomi/20141014113210-92-6355/tergerusnya-penjualantiket-via-travel/ 
Jeon, H. M., Ali, F., \& Lee, S. W. (2018). Determinants of consumers' intentions to use smartphones apps for flight ticket bookings. Service Industries Journal, 39(5-6), 385-402. https://doi.org/10.1080/02642069.2018.1437908

Kim, H. bumm, Kim, T. (Terry), \& Shin, S. W. (2009). Modeling roles of subjective norms and eTrust in customers' acceptance of airline B2C eCommerce websites. Tourism Management, 30(2), 266-277. https://doi.org/10.1016/j.tourman.2008.07.001

Lee, F. H., \& Wu, W. Y. (2011). Moderating effects of technology acceptance perspectives on e-service quality formation: Evidence from airline websites in Taiwan. Expert Systems with Applications, 38(6), 7766-7773. https://doi.org/10.1016/j.eswa.2010.12.131

Lee, K.-F., Haque, A., Maulan, S., \& Abdullah, K. (2019). Determining intention to buy air e-tickets in Malaysia. Management Science Letters, 9, 933-944. https://doi.org/10.5267/j. msl.2019.2.009

Mayer, R. C., Davis, J. H., Schoorman, F. D., Mayer, R. C., \& Davis, J. H. (1995). An Integrative Model of Organizational Trust. The Academy of Management Review, 20(3), 709-734.

Mohd Suki, N., \& Mohd Suki, N. (2017). Flight ticket booking app on mobile devices: Examining the determinants of individual intention to use. Journal of Air Transport Management, 62, 146-154. https://doi.org/10.1016/j.jairtraman.2017.04.003

Nguyen, T. D., \& Hyunh, P. A. (2018). The Roles of Perceived Risk and Trust on E-Payment Adoption. Econometrics for Financial Applications, 760. https://doi.org/10.1007/9783-319-73150-6

Oliver, R., \& DeSarbo, W. S. (1988). Response Determinants in Satisfaction Judgments. Journal of Consumer Research, 14(4), 495-507. https://doi.org/10.1086/209131

Prodjo, W. A. (2015). Tahun 2016, Penggunaan Aplikasi "Online Travel Agent" akan Meningkat. Diakses July 3, 2017, dari http://travel.kompas.com/read/2015/12/29/181500027/ Tahun.2016.Penggunaan.Aplikasi.Online.Travel.Agent.akan.Meningkat.

Suh, B., \& Han, I. (2002). Effect of trust on customer acceptance of Internet banking. Electronic Commerce Reserach and Applications, 1(3), 247-263.

Susanto, A., Chang, Y., \& Ha, Y. (2016). Determinants of Continuance intention touse the smartphone banking service. An Extension to the expectation-confirmation model. Industrial Management \& Data Systems, 116(3), 508-525. https://doi.org/dx.doi. org/10.1108/IMDS-07-2015-0266

Szymanski, D. M., \& Henard, D. H. (2001). Customer Satisfaction: A Meta-Analysis of the Empirical Evidance. Journal of the Academy of Marketing Science, 29(1), 16-35. https:// doi.org/10.1177/009207030102900102

Thong, J. Y. L., Hong, S. J., \& Tam, K. Y. (2006). The effects of post-adoption beliefs on the expectation-confirmation model for information technology continuance. International Journal of Human Computer Studies, 64(9), 799-810. https://doi.org/10.1016/j. ijhcs.2006.05.001

Venkatesh, V., \& Morris, M. G. (2000). Why Don't Men Ever Stop to Ask For Directions? Gender, Social Influence, and Their Role in Technology Acceptance and Usage Behaviour. MIS Quarterly, 24(1), 115-139. 
Venkatesh, V., Thong, J. Y. L., Chan, F. K. Y., Hu, P. J., \& Brown, S. A. (2011). Extending the two-stage information systems continuance model: incorporating UTAUT predictors and the role of context. Information System Journal, 21(6), 527-555. https://doi. org/10.1111/j.1365-2575.2011.00373.x

Vila, N., \& Kuster, I. (2011). Consumer feelings and behaviours towards well designed websites. Information and Management, 48(4-5), 166-177. https://doi.org/10.1016/j. im.2011.04.003

We Are Social Singapore. (2017). Digital in 2017 : Southeast Asia, A Study of Internet, Social Media, and Mobile Use Throught The Region. Diakses July 2, 2017, dari https://www. slideshare.net/wearesocialsg/digital-in-2017-southeast-asia

Yu, L., Cao, X., Gong, M., \& Adeel, L. (2018). Understanding mobile payment users ' continuance intention: a trust transfer perspective. Internet Research, (February). https://doi. org/10.1108/IntR-11-2016-0359

Zhou, W., Tsiga, Z., Li, B., Zheng, S., \& Jiang, S. (2018). What influence users' e-finance continuance intention? The moderating role of trust. Industrial Management and Data Systems, 118(8), 1647-1670. https://doi.org/10.1108/IMDS-12-2017-0602 